
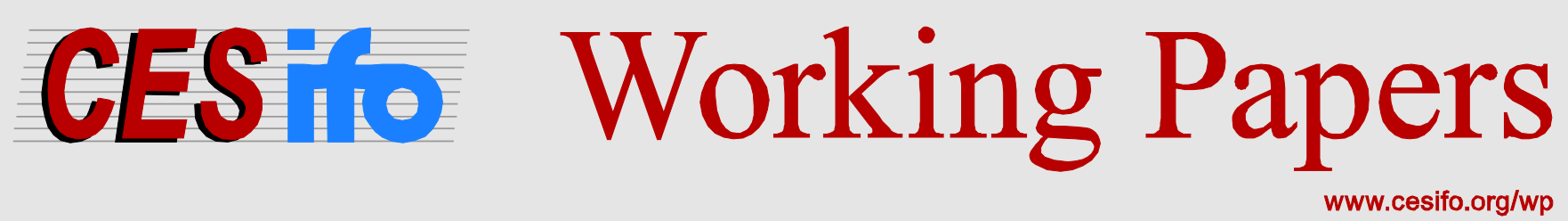

\title{
Does Distance Matter? \\ Tuition Fees and Enrollment of First-Year Students at German Public Universities
}

\author{
Kerstin Bruckmeier \\ Georg-Benedikt Fischer \\ Berthold U. Wigger
}

CESIFO WORKING PAPER NO. 4258

CATEGORY 5: ECONOMICS OF EDUCATION

MAY 2013

An electronic version of the paper may be downloaded

- from the SSRN website:

- from the RePEc website:

- from the CESifo website:

WwW.SSRN.com

www.RePEc.org

www.CESifo-group.org/wp

\section{CESifo}




\title{
Does Distance Matter? Tuition Fees and Enrollment of First-Year Students at German Public Universities
}

\begin{abstract}
We use the recent introduction of tuition fees at public universities in seven of the sixteen German states to identify the effects of tuition fees on university enrollment of first-year students at German public universities. Our study differs from previous research in two important ways. Firstly, we take into account the location of universities and include a spatial variable, which measures the distance between a fee-imposing university and the nearest feefree alternative. Secondly, we use panel data that allows us to control for unobserved heterogeneity between universities. Our results suggest that enrollment at universities that impose a tuition fee and that are located close to fee-free universities experience a decrease in enrollment that is twice as large as the decrease at universities that are further away from feefree universities. We also find gender differences in enrollment behavior. Enrollment numbers of female students at universities that are located far away from fee-free alternatives are significantly less affected by the introduction of tuition fees than are enrollment numbers of male students.
\end{abstract}

JEL-Code: I220, I230, H750.

Keywords: tuition fees, distance measure, enrollment rates, gender effects.

Kerstin Bruckmeier

Karlsruhe Institute of Technology

Chair of Public Economics and Public

Finance, Kronenstraße 34

Germany - 76133 Karlsruhe

kerstin.bruckmeier@kit.edu
Georg-Benedikt Fischer

Karlsruhe Institute of Technology

Chair of Public Economics and Public

Finance, Kronenstraße 34

Germany - 76133 Karlsruhe

georg-benedikt.fischer@kit.edu

Berthold U. Wigger

Karlsruhe Institute of Technology

Chair of Public Economics and Public Finance

Kronenstraße 34

Germany - 76133 Karlsruhe

berthold.wigger@kit.edu

May 14, 2013

Supported by the German Federal Ministry of Education and Research (BMBF) (grant no. 01 PW 11015). Any opinions expressed here are those of the authors and not those of the BMBF. 


\section{Introduction}

In Germany higher education at public universities was free of charge until 2005. Between 2006 and 2007 seven out of the 16 German states implemented tuition fees of about 1,000 Euro per year. ${ }^{3}$ In five of the seven states fees have since been abolished only a few years after being introduced; in the remaining two states, abolishment is planned. The abolishment reflects intensive public and political concerns about potential negative effects of tuition fees on higher education participation.

International empirical evidence tends to support these concerns. Studies for the US have predominantly found a negative effect of an increase in tuition fees on higher education enrollment. Based on a meta analysis of studies conducted between 1967 and 1982, Leslie and Brinkman (1987) conclude that an increase in college costs of $\$ 100$ reduces the enrollment rate by 0.6 to 0.8 percentage points. Heller (1997) updates these results by considering studies for the US between 1975 and 1996 and reports findings of a negative effect that amounts to an average decrease in enrollment of 5 to 10 percentage points for a $\$ 1,000$ increase in tuition fees. Kane (1994) considers university enrollment between 1972 and 1988 and finds that an increase in direct college costs of $\$ 1,000$ leads to a decline of 1.2 to 4.6 percentage points in average enrollment rates of white high school graduates. Hemelt and Marcotte (2008) focus on enrollment in public four-year colleges between 1991 and 2007. For a $\$ 1,000$ increase in tuition fees they find a negative effect on enrollment of 2.5 percentage points. Studies on enrollment in Europe provide results that are almost in the same range as the results for the US. WinterEbmer and Wirz (2002) use data from 14 European countries and find that high school graduates in countries with tuition fees have a significantly lower enroll-

\footnotetext{
${ }^{3}$ As with many continental European countries these tuition fees are rather modest in comparison to the United States and the United Kingdom (CESifo, 2011). Among the EU27 only four countries charge tuition fees at public universities of more than 1,200 US-Dollars per year (OECD, 2011).
} 
ment probability. Dearden, Fitzsimons and Wyness (2011) show that in the UK a $£ 1,000$ increase in tuition fees results in a decrease in higher education participation of 3.9 percentage points.

For Germany, only few studies exist and these studies show rather mixed empirical evidence. Hübner (2012) finds a negative effect of 2.7 percentage points on aggregated enrollment rates in fee introducing states. Employing the same data base, however, Bruckmeier and Wigger (2013) show that this result is not robust if additional control variables are taken into account. Using survey data on high school students' willingness to participate in higher education, Helbig, Baier and Kroth (2012) also find no effect of tuition fees.

The prior studies are based on the choice of either to study or not to study. In an analysis on the impact of tuition fees in England Wilkins, Shams and Huisman (2012) discuss a third, spatial, option, namely the option of studying abroad. These authors argue that the recent tuition fee increase in England may act as a "push factor" for international student mobility. In Germany such an effect should even be of more relevance since only seven out of 16 German states introduced tuition fees. While the interstate mobility of German students was rather low in the past, it might have increased after the introduction of tuition fees in some states.

Two studies focus on the effect of the introduction of tuition fees on interstate mobility of German students. The results of Dwenger, Storck and Wrohlich (2012) indicate that the application rate of high school graduates for studying in their home state is reduced by 2 percentage points in fee states. However, the data used in their study only covers enrollment of medicine and dentistry students who are allocated to universities on the basis of a specific quantity rationing scheme. Alecke and Mitze (2012) find that tuition fees reduce net immigration by 4.1 to 5.5 percent in fee states. Both studies provide no strong evidence that a substantial number 
of students tried to avoid tuition fees by moving to another state. Presumably, migration costs exceed tuition costs for the majority of affected students.

Given the mixed empirical results and the political significance of tuition fees, we aim to provide new evidence on the relationship between tuition fees and enrollment at public universities in Germany. Our analysis employs data of all large German universities and compares enrollment trends between universities in fee-free states and fee states. The changes in enrollment measured at the university level cover the individual decisions on whether to study or not as well as the decision on where to study. Since high school graduates can choose between fee-charging universities and fee-free universities in Germany, the distance between the place of residence and the next fee or fee-free university can be expected to be an important determinant of the decision to enroll into higher education and the choice of the university. Since universities are not equally distributed across the states and feefree as well as fee-charging states vary significantly in their size, individual costs of mobility to avoid tuition fees differ substantially. Hence, the potential negative effect of tuition fees should be more relevant for fee universities that are located close to fee-free universities. Contrary to former studies, our analysis takes into account these spatial heterogeneities by making use of a variable that measures the distance between public universities in Germany. Our results suggest that the effect of tuition fees on enrollment differs markedly depending on the distance of the respective fee university to the nearest fee-free university. A further finding is that males and females differ in their enrollment behavior. Male students are much more likely to switch to a fee-free university than their female counterparts.

The remainder of the paper is organized as follows. Section 2 describes the institutional background of the higher education system in Germany and the recent introduction of tuition fees. The dataset we employ is presented in Section 3. 
Section 4 establishes the empirical models. The results are discussed in Section 5. Section 6 concludes.

\section{Institutional Background}

Apart from fees for long term students charged in some federal states, studying at public universities in Germany has been free of charge since the 1970s. This changed after a ruling of the German Federal Constitutional Court in 2005 which allowed the federal states to introduce tuition fees at public universities. The federal states Lower-Saxony and North Rhine-Westphalia introduced tuition fees as of the winter term 2006/2007. Baden-Württemberg, Bavaria and Hamburg followed suit in the summer term 2007, and Hesse and Saarland in the winter term 2007/2008. No federal state from former Eastern Germany and no Western German state led by the Social-Democratic Party of Germany has introduced tuition fees.

Although tuition fee regulations vary between the federal states, students had to pay around 1,000 Euro per year at a public university in fee states. For political reasons tuition fees were withdrawn in most states after a relatively short period of time. Hesse abolished tuition only one year after its introduction as of the winter term 2008/2009 followed by Saarland where studying was free again as of the summer term 2010. In all states the withdrawal of tuition fees was due to a change in the governing majority after states elections. The remaining states Bavaria and Lower Saxony already intend to abolished tuition fees in the near future. Table 1 gives a brief overview on the history of the introduction and withdrawal of tuition fees in the German federal states.

Clearly, the total sum of tuition payments depends on the duration of study. The total sum of tuition payments for a degree at a public university varies on av- 


\begin{tabular}{|c|c|c|c|c|}
\hline \multicolumn{5}{|c|}{ Timetable of tuition fees at public universities in Germany } \\
\hline & $\begin{array}{l}\text { Introduction } \\
\text { announced }\end{array}$ & Introduction & $\begin{array}{l}\text { Abolishment } \\
\text { announced }\end{array}$ & Abolished \\
\hline $\begin{array}{l}\text { Baden- } \\
\text { Württemberg }\end{array}$ & December 2005 & ST 2007 & $\begin{array}{l}\text { July } 2011 \\
\text { (March 2011**) }\end{array}$ & ST 2012 \\
\hline Bavaria & May 2006 & ST 2007 & February $2013^{* * *}$ & intended \\
\hline Hamburg & June 2006 & ST 2007 & $\begin{array}{l}\text { September } 2011 \\
\text { (February } 2011^{* *} \text { ) }\end{array}$ & WT 2012/13 \\
\hline Hesse & October 2006 & WT 2007/08 & $\begin{array}{l}\text { July } 2008 \\
\left(\text { January } 2008^{* *} \text { ) }\right.\end{array}$ & WT 2008/09 \\
\hline $\begin{array}{l}\text { Lower } \\
\text { Saxony }\end{array}$ & December 2005 & WT 2006/07* & January $2013^{* *}$ & intended \\
\hline $\begin{array}{l}\text { North Rhine- } \\
\text { Westphalia }\end{array}$ & March 2006 & WT 2006/07* & $\begin{array}{l}\text { February } 2011 \\
\left(\text { May } 2010^{* *}\right)\end{array}$ & WT 2011/12 \\
\hline Saarland & July 2006 & WT 2007/08 & $\begin{array}{l}\text { February } 2010 \\
\text { (August 2009**) }\end{array}$ & ST 2010 \\
\hline
\end{tabular}

Table 1: Timetable of the German tuition fees in the different federal states (ST = summer term, WT = winter term); ${ }^{*}$ only for first year students, fees for all students as of summer term 2007; ${ }^{* *}$ change in governing majority after state elections; ${ }^{* * *}$ referendum for the abolishment of tuitions fees.

erage between 3,500 Euro and 6,000 Euro. A peculiar characteristic of tuition fees at German public universities is the variety of fee exemptions. One example is the arrangement in Bavaria which stipulates that students from families with three or more children do not have to pay tuition fees. ${ }^{4}$ Furthermore, the introduction of tuition fees was accompanied by a very comprehensive and generous public student loans program. The loans complemented a support program for German students from low income families ("BAföG") $)$ ). Altogether, fee exemptions and student support programs are very generous and targeted to students from low income families.

\section{Data}

Our empirical analysis is based on data of the 65 largest public universities in Germany between 2003 and 2010. These universities are characterized by hav-

\footnotetext{
${ }^{4}$ Section 71, subsection 5, second sentence, Bavarian University and College Act.

${ }^{5}$ The amount depends on the income of the student's parents and can be up to 670 Euro per month. One half is granted as a subsidy and the other half as a loan, but no student has to pay back more than 10,000 Euro ("Kappungsgrenze").
} 
ing at least 1,000 first year students in the winter term 2007/2008. Our dependent variable is the number of freshman in the winter term of each observed year, i.e., winter term 2003/2004 to winter term 2010/2011, that have not been enrolled at a university before (Studenten im ersten Hochschulsemester). We take these numbers, differentiated by female and male students, from the Federal Statistical Office of Germany. ${ }^{6}$ Since our dataset consists of 65 universities and 8 years of observations, we have 520 observations in total. Since we include the same universities over the whole observation period, we can employ panel data techniques.

To study the effects of tuition fees on the number of enrollees, we consider two different cost of study variables, tuition fees and mobility costs. Information on whether tuition fees are charged or not in a specific federal state and year can be gathered from Table 1. To approximate mobility costs, we measure the distance between a fee-charging university and the closest fee-free university. The distance is measured as the airline distance in kilometers, which is a good approximation for the street distance between universities, given the density of the German road and railway infrastructure.

The overall number of first year students were increasing during the last years. On average the number of first year students increased by $41.4 \%$ between the winterterm 2000/2001 and 2010/2011. However, the increase in engineering students was higher than in all other groups. The number of first year engineering students increased by $76.9 \%$ and their relative share of all first year students climbed from $16.8 \%$ to $21.0 \%$ (see Table A1 in the Appendix). To take into account different trends across different fields of studies, we include a dummy variable for universities that are members of the Society of German Universities of Technology, which is a proxy for universities with a specialization in engineering studies. ${ }^{7}$

\footnotetext{
${ }^{6}$ Data from the publication Fachserie 11, Reihe 4.1.

${ }^{7} T U 9$, which consists of the nine largest German Universities of Technology, namely RWTH Aachen, TU Berlin, TU Braunschweig, TU Darmstadt, TU Dresden, University of Hannover, Karlsruhe Institute of Technology, TU Munich and University of Stuttgart.
} 
During our observation period some universities were awarded the status of a so-called elite university by an expert commission (Excellence Initiative). All elite universities received additional public funds and experienced a gain in their reputation. Therefore, our control variables include a dummy variable for universities which got the elite status. In October 2006 the LMU Munich, the TU Munich and the University of Karlsruhe were awarded. We assume that the first time it might have had an effect on enrollment numbers was in the winter term $2007 / 2008$, so that the dummy variable elite takes the value 1 as of the winter term 2007/2008. In October 2007 also the RWTH Aachen, the Free University of Berlin, the University of Freiburg, the University of Göttingen, the University of Heidelberg and the University of Konstanz were awarded the elite status, so that for these universities the dummy variable elite takes the value 1 as of the winter term 2008/2009.

We also consider the number of new high school graduates in the region where a university is located. This is because it can be expected that the amount of first year students is affected by this number. In fact, there is some empirical evidence suggesting that German students are rather immobile. ${ }^{8}$ We employ data on the number of new high school graduates in the administrative district (Landkreis) and the bordering administrative districts of all universities in our sample. The number of administrative districts that is considered for a university ranges between three and twelve. Data on new high school graduates at the level of the 437 German districts is published by the Statistical Offices of the 16 German states.

Finally, we include regional labor market variables as additional controls. Our dataset contains information about the unemployment rate, the wage gap and the median wage at the states level. The data comes from the German Federal Employment Agency. As specific employment data on university graduates is not available at the states level, the unemployment rate is calculated for the whole pop-

\footnotetext{
${ }^{8}$ See Büttner, Kraus and Rincke (2003) and Spiess and Wrohlich (2010). A similar result has been found by Denzler and Wolter (2010) for the German part of Switzerland.
} 
ulation in the state the university is located in. The median wage is calculated for the earnings distribution of full-time employees who finished a vocational training after high school. The wage gap is the ratio of the wage of full-time employees who participated in university education and those who decided to participate in vocational training after graduation.

Table 2 gives a brief overview on the descriptive statistics of our data.

\begin{tabular}{|lllll|}
\hline \multicolumn{5}{|c|}{ Descriptive statistics } \\
\hline & Mean & $\begin{array}{l}\text { Standard } \\
\text { Deviation }\end{array}$ & Min & Max \\
First semester students & 2,920 & 1,286 & 646 & 7,669 \\
Fee dummy & 0.34 & 0.48 & & \\
Distance* & 124.7 & 62.30 & 23 & 286 \\
School graduates & 4,916 & 4,139 & 541 & 20,154 \\
School graduates female & 2,758 & 2,338 & 284 & 11,297 \\
School graduates male & 2,158 & 1,805 & 257 & 8,857 \\
Elite dummy & 0.06 & 0.23 & & \\
Engineering dummy & 0.14 & 0.35 & & \\
Unemployment rate & 9.82 & 4.15 & 4.1 & 20.5 \\
Wage gap & 1.72 & 0.09 & 1.54 & 1.95 \\
Median Wage & 2,598 & 372.76 & 1,781 & 3,163 \\
\hline
\end{tabular}

Table 2: Descriptive statistics of the employed data; *only fee universities with distance larger than zero included.

\section{The Empirical Model}

In order to evaluate the effect of tuition fees on enrollment in higher education we compare the development of university enrollment across fee-free states and feeintroducing states. The dependent variable is the number of enrollees $y_{i s t}$, where $i$ is the index of the university in state $s$ observed in year $t$. We estimate all models for males and females separately. We make use of a regression difference-indifferences approach as we try to identify the effect of a treatment, i.e., the intro- 
duction of tuition fees in some of the observed federal states, that occurs during our observation period.

We start our empirical analysis with a simple specification (Model 1), which does not consider distances between fee-charging and fee-free universities. As a cost of study variable it only includes the variable $f e e_{s t}$. Furthermore, it includes a vector of control variables $X_{i s t}$, year dummies $\lambda_{t}$, state dummies $\rho_{s}$ and the error term $\varepsilon_{i s t}$ :

$$
y_{i s t}=\beta_{0}+\beta_{1} f e e_{s t}+\gamma X_{i s t}^{\prime}+\lambda_{t}+\rho_{s}+\varepsilon_{i s t} .
$$

The dummy variable fee takes on the value 1 for each respective year that tuition fees are charged in the winter term in the federal state the university is located in. Because the average fee that students had to pay was almost equal across universities and states - on average students had to pay 1,000 Euro per year - we assume a constant treatment intensity across universities. Although tuition in Germany is not very high, we generally expect the introduction of fees to have a rather negative effect on enrollment numbers. As mentioned in Section 2, the introduction of tuition fees resulted from a ruling of the German Federal Constitutional Court in 2005 and the subsequent decisions of several state parliaments. Therefore, it can be seen as an exogenous treatment because both the decision of the Federal Constitutional Court and the decisions of the respective state parliaments were not foreseeable for either potential students or affected universities. For individual universities it was an exogenous event whether it became a fee university or whether it remained fee free. However, in order to test for potential endogeneity of the treatment we will also examine the effect of a placebo treatment (i.e., the introduction of fees) already occurring in the year $2005 .^{9}$

\footnotetext{
${ }^{9}$ The federal state Hesse is excluded in this test as it implemented tuition fees for only one year and is therefore not comparable to other federal states.
} 
One could argue that the fee dummy variable should already assume the value 1 once a state parliament has announced the decision to impose tuition fees at all its state universities. This is because potential students then will anticipate that they do have to pay tuition for a major part of their studies. In the same vein, the fee dummy variable might already assume the value 0 again as soon as the withdrawal of the fees is announced. To take into account these possibilities, we test for different treatment periods.

The vector of control variables $X$ includes a dummy variable ingfocus that indicates if a university has a strong focus on engineer studies and controls for the above average increase in first year students in the fields of engineering in our observation period. As male students are traditionally over-represented in these fields of study, we expect this variable to be more significant for males.

The dummy variable elite indicates whether or not a university was awarded the status of elite university during the observation period. The variable takes the value 1 as soon as the elite status was announced. Since the elite status is seen as prestigious, we expect elite to have a positive effect on the number of first year students.

The number of first year students also depends on the number of new high school graduates. This number differs widely between eastern and western German states. After German reunification average birth rates in the eastern states dropped strongly, and these baby-bust generations determine the number of new east German high school graduates since 2007. Between 2002 and 2010 the number of high school graduates in the east German states decreased by 25 percent, whereas in the western states this number increased by 42 percent. ${ }^{10}$ The variable graduates contains the number of students that achieve the general qualification for university entrance in the administrative district (Landkreis) of the university

\footnotetext{
${ }^{10}$ The figures refer to data about high school graduates (Abiturienten) reported by the Federal Statistical Office.
} 
and all bordering administrative districts. It serves as a proxy for the supply of potential students. We expect that a higher number of new high school graduates in the surrounding area of a university positively affects that university's number of first year students. However, this positive effect may be moderated by a couple of related factors. On the one hand, an increasing number of high school graduates may lead to crowding at universities. On the other hand, an absolute increase in the number of high school graduates does not necessarily lead to a proportional increase in the number of individuals who are inclined to participate in university education (Kane, 1994). Therefore, we also consider the square of the number of high school graduates.

As mentioned in Section 3 we utilize three labor market variables. The first one is the unemployment rate at the state level, unemployment. Unemployment may affect the decision to study in three different ways. Firstly, a higher unemployment rate may reduce the monetary return of studying as the risk of not finding an appropriate occupation after studying increases. Secondly, a higher unemployment rate may foster participation in higher education to the extent that education may serve as a measure against unemployment. Thirdly, unemployment as such reduces the opportunity costs of studying. Therefore, we are ambivalent about the sign of the coefficient of the variable unemployment. The second labor market variable is the wagegap. As a higher wage gap implies a higher return of tertiary education, we expect the variable to be positively correlated with the number of enrollees. The third labor market variable is the medianwage of high school graduates who finished a vocational training after high school instead of studying. A higher wage for high school graduates who completed a vocational training makes studying as an alternative less attractive, so that the effect of the variable medianwage on first year students should be negative . 
Finally, the year and state dummies, $\lambda_{t}$ and $\rho_{s}$, are included to control for possible aggregate time trends and possible differences between the German states.

In our base specification we add the variable distance to equation (1):

$$
y_{i s t}=\beta_{0}+\beta_{1} \text { fee }_{s t}+\beta_{2} \text { distance }_{i t}^{4}+\gamma X_{i s t}^{\prime}+\lambda_{t}+\rho_{s}+\varepsilon_{i s t} .
$$

Thus, in our base specification we explicitly take into account the distances between fee and fee-free universities. Figure 1 shows the regional distribution of the universities we consider in our analysis on a map of the 16 German states. Universities in fee states differ substantially in their distances to universities in fee free states. This implies that, depending on the specific region in which a high school graduate lives, the mobility costs of choosing a fee-free instead of a fee-charging university substantially differ as well. We measure these costs by the variable distance, which measures the airline distance for each fee-charging university to the closest fee-free university. The distance variable is zero as long as the university does not charge fees. As soon as the university charges fees, the distance variable becomes strictly positive. Thus, the value of the variable distance can change over time. Hesse introduced and abolished tuition fees within our observation period so that the distances to the next fee free university of Hessian universities are first zero, than positive, and than zero again.

Since German students are rather immobile (Büttner, Kraus and Rincke, 2003; Spiess and Wrohlich, 2010), mobility costs should play an important role in the choice of the place of study for high school graduates. Due to the unequal spatial distribution of universities across states, some high school graduates face lower costs of avoiding tuition fees by studying at the next fee-free university than others. We assume that migration costs - monetary and non-monetary - increase disproportionally with distance. One reason is that from a certain distance on it 


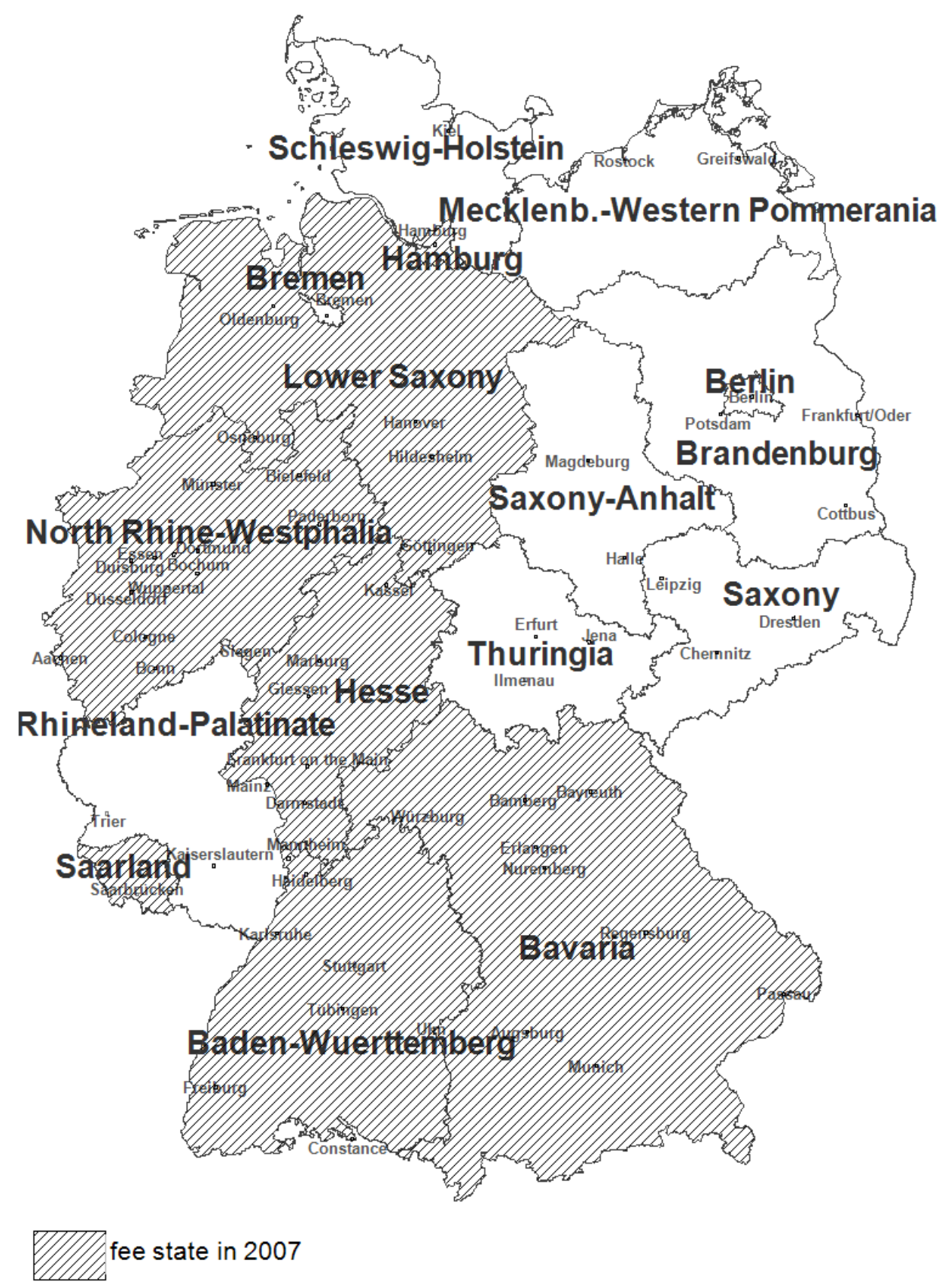

Figure 1: University cities in Germany 
is more likely that potential students change their residence rather than commuting to the university so that the monetary costs greatly increase. A second reason is that non-monetary costs like leaving social networks increase disproportionally with distance. In order to capture the disproportional increase in mobility costs when the distance increases, we employ a convex cost function. More precisely, we use the distance variable distance to the power of four in our base specification. We also consider a specification with a complete polynomial function of the distance to the power of four and a semi-parametric specification. We expect that the enrollment numbers of fee-charging universities that are located close to feefree universities are more strongly affected by the introduction of tuition fees than fee-charging universities that are farther away from fee-free universities.

Table 3 gives a brief overview of the explanatory and control variables and the expected signs of the respective coefficients.

\begin{tabular}{|lc|}
\hline & Expected sign of coefficient \\
fee & - \\
distance & + \\
ingfocus & $+/-$ \\
elite & + \\
graduates $_{\text {graduates }}$ & + \\
unemployment $_{\text {wagegap }}$ & - \\
medianwage & $?$ \\
\hline
\end{tabular}

Table 3: Overview of explanatory and control variables

In the following we consider four estimation models. Model 1 and Model 2 are OLS estimations of equations (1) and (2), respectively. In order to exploit the panel data character of our dataset, we additionally employ panel data estimators. Model 3 is a fixed effects estimation of equation (2).

To avoid potential problems of within group correlation that might lead to downward biased standard errors (Moulton, 1986; Moulton, 1990; Donald and 
Lang, 2007), we use clustered standard errors in all specifications. ${ }^{11}$ Standard errors are clustered at the states level since the treatment as well as some of the controls only vary at the states level.

A potentially serious problem that has to be addressed when applying differencein-differences estimation is serial correlation of the error terms. As pointed out by Bertrand, Duflo and Mullainathan (2004) serial correlation can lead to severe underestimation of error terms and, therefore, to significant effects that do not exist in reality. For small group sizes such as our dataset with 16 federal states Bertrand, Duflo and Mullainathan (2004) propose to ignore the time-series information in the dataset. This is done by averaging all variables in the period before and after the treatment and running the regression for these two periods. As Hesse is the only state which both implemented and withdrew tuition fees during the observation period, we exclude it from this robustness check.

\section{Estimation Results}

Tables 4 to 6 report the results of our regression analysis. We first discuss the effects of the control variables and then consider the effects of the tuition fee and distance variables.

\section{Effects of control variables}

The overall effect of the variable ing focus is positive and significant for all students and for the subgroup of males (Tables 4 and 5). Distinguishing between males and females, it is positive for male students and negative for female students (Tables 5 and 6). However, the effect is not significant for female students.

The elite university status seems to have a positive impact on the number of enrollees. The effect is highly significant in Model 1 and Model 2. When looking

\footnotetext{
${ }^{11}$ As for example described in Angrist and Pischke (2009), based on Liang and Zeger (1986).
} 
at the panel data model, however, the size of the effect of the elite status of a university decreases substantially. It is insignificant in the fixed effects model (3) for both males and females. This could imply that the dummy for elite universities is correlated with other university specific unobserved effects.

As expected, the number of new high school graduates in the surrounding area of the university positively affects the number of first year students, males as well as females, though the effect is only significant in the panel data model (Models 3). Our results indicate that each additional high school graduate leads to an increase of approximately 0.18 additional enrollees. The decreasing numbers of high school graduates over the last years in many regions of former Eastern Germany thus had a negative impact on the number of first year students of universities located in these regions, whereas the increasing number of high school graduates in prosperous metropolitan areas like Munich, Berlin, Hamburg and Cologne had a positive impact. The variable graduates ${ }^{2}$ was expected to curb the positive effect of graduates and therefore to have a negative impact on the number of enrollees. This expectation only holds for the panel data model, but the effect is not significant.

A higher unemployment rate is associated with a small increase in the number of enrollees. The effect is significant for males and all first year students in the panel data models. For females it is insignificant in all specifications. However, the effect is also modest for males. The coefficient of the variable wagegap is positive but insignificant in all models for all first year students and for females. For males we find a significant positive effect in the panel data model.

Overall, the results for our control variables do not show any surprising effects. While the coefficients are similar in sign, size and significance in the two panel data models, they vary distinctly between the OLS model and the panel data models. Therefore, unobserved university-specific fixed effects should be taken into 


\begin{tabular}{|c|c|c|c|}
\hline \multicolumn{4}{|c|}{ All first year students } \\
\hline MODEL & (1) & (2) & (3) \\
\hline fee & $\begin{array}{c}-431.0 * * * \\
(87.81)\end{array}$ & $\begin{array}{c}-472.6^{* * * *} \\
(92.38)\end{array}$ & $\begin{array}{c}-309.7 * * * \\
(60.31)\end{array}$ \\
\hline distance $^{4}$ & & $\begin{array}{c}6.51 \mathrm{e}-08 * * * \\
(1.86 \mathrm{e}-08)\end{array}$ & $\begin{array}{c}5.62 \mathrm{e}-08 * * * \\
(1.51 \mathrm{e}-08)\end{array}$ \\
\hline ingfocus & $\begin{array}{c}833.3^{* *} \\
(308.8)\end{array}$ & $\begin{array}{c}834.6^{* *} \\
(312.8)\end{array}$ & \\
\hline elite & $\begin{array}{c}1,463 * * * \\
(336.4)\end{array}$ & $\begin{array}{c}1,368 * * * \\
(273.6)\end{array}$ & $\begin{array}{l}170.5 \\
(144.1)\end{array}$ \\
\hline graduates & $\begin{array}{l}0.109 \\
(0.158)\end{array}$ & $\begin{array}{l}0.102 \\
(0.155)\end{array}$ & $\begin{array}{l}0.188^{*} \\
(0.0944)\end{array}$ \\
\hline graduates $^{2}$ & $\begin{array}{l}4.16 \mathrm{e}-06 \\
(8.65 \mathrm{e}-06)\end{array}$ & $\begin{array}{l}4.45 \mathrm{e}-06 \\
(8.54 \mathrm{e}-06)\end{array}$ & $\begin{array}{c}-4.66 \mathrm{e}-06 \\
(4.46 \mathrm{e}-06)\end{array}$ \\
\hline unemployment & $\begin{array}{l}-5.212 \\
(47.07)\end{array}$ & $\begin{array}{l}5.394 \\
(44.26)\end{array}$ & $\begin{array}{l}56.54 * \\
(31.67)\end{array}$ \\
\hline wagegap & $\begin{array}{l}305.5 \\
(1,150)\end{array}$ & $\begin{array}{l}388.2 \\
(1,140)\end{array}$ & $\begin{array}{l}992.8 \\
(666.4)\end{array}$ \\
\hline medianwage & $\begin{array}{l}1,432 \\
(3,344)\end{array}$ & $\begin{array}{l}1,182 \\
(3,282)\end{array}$ & $\begin{array}{l}-525.0 \\
(2,292)\end{array}$ \\
\hline yeardummies & yes & yes & yes \\
\hline statedummies & yes & yes & \\
\hline Constant & $\begin{array}{l}-4,382 \\
(8,697)\end{array}$ & $\begin{array}{l}-4,044 \\
(8,416)\end{array}$ & $\begin{array}{l}1,904 \\
(6,181)\end{array}$ \\
\hline Observations & 520 & 520 & 520 \\
\hline $\begin{array}{l}R^{2} \\
\text { Panel data }\end{array}$ & 0.496 & 0.497 & $\begin{array}{c}0.397 \\
\mathrm{FE}\end{array}$ \\
\hline
\end{tabular}

Clustered standard errors in parentheses

$* * * \mathrm{p}<0.01, * * \mathrm{p}<0.05, * \mathrm{p}<0.1$

Table 4: Regression results for all first year students 


\begin{tabular}{|c|c|c|c|}
\hline \multicolumn{4}{|c|}{ Male first year students } \\
\hline MODEL & $(1)$ & (2) & (3) \\
\hline fee & $\begin{array}{c}-206.5^{* * *} \\
(51.93)\end{array}$ & $\begin{array}{c}-209.5^{* * *} \\
(52.43)\end{array}$ & $\begin{array}{c}-152.8^{* * *} \\
(36.46)\end{array}$ \\
\hline distance $^{4}$ & & $\begin{array}{l}4.72 \mathrm{e}-09 \\
(8.93 \mathrm{e}-09)\end{array}$ & $\begin{array}{c}2.40 \mathrm{e}-08 * * \\
(9.73 \mathrm{e}-09)\end{array}$ \\
\hline ingfocus & $\begin{array}{c}1,253 * * * \\
(142.2)\end{array}$ & $\begin{array}{c}1,254 * * * \\
(142.7)\end{array}$ & \\
\hline elite & $\begin{array}{c}734.9 * * * \\
(181.0)\end{array}$ & $\begin{array}{c}728.0 * * * \\
(188.4)\end{array}$ & $\begin{array}{l}150.4 \\
(108.1)\end{array}$ \\
\hline graduates & $\begin{array}{c}0.0566 \\
(0.134)\end{array}$ & $\begin{array}{c}0.0555 \\
(0.135)\end{array}$ & $\begin{array}{l}0.183 * \\
(0.0894)\end{array}$ \\
\hline graduates $^{2}$ & $\begin{array}{l}1.32 \mathrm{e}-05 \\
(1.63 \mathrm{e}-05)\end{array}$ & $\begin{array}{l}1.33 \mathrm{e}-05 \\
(1.63 \mathrm{e}-05)\end{array}$ & $\begin{array}{c}-9.65 e-06 \\
(9.64 \mathrm{e}-06)\end{array}$ \\
\hline unemployment & $\begin{array}{l}-1.605 \\
(24.41)\end{array}$ & $\begin{array}{l}-0.846 \\
(24.11)\end{array}$ & $\begin{array}{l}30.00 * \\
(14.60)\end{array}$ \\
\hline wagegap & $\begin{array}{l}-222.5 \\
(688.3)\end{array}$ & $\begin{array}{l}-216.6 \\
(687.0)\end{array}$ & $\begin{array}{l}568.7 * \\
(305.4)\end{array}$ \\
\hline medianwage & $\begin{array}{l}514.5 \\
(1,746)\end{array}$ & $\begin{array}{l}496.2 \\
(1,740)\end{array}$ & $\begin{array}{l}-534.2 \\
(1,178)\end{array}$ \\
\hline yeardummies & yes & yes & yes \\
\hline statedummies & yes & yes & \\
\hline Constant & $\begin{array}{l}-1,048 \\
(4,660)\end{array}$ & $\begin{array}{l}-1,022 \\
(4,650)\end{array}$ & $\begin{array}{l}1,469 \\
(3,307)\end{array}$ \\
\hline $\begin{array}{l}\text { Observations } \\
R^{2} \\
\text { Panel data }\end{array}$ & $\begin{array}{c}520 \\
0.691\end{array}$ & $\begin{array}{c}520 \\
0.691\end{array}$ & $\begin{array}{c}520 \\
0.363 \\
\text { FE }\end{array}$ \\
\hline
\end{tabular}

Clustered standard errors in parentheses

*** $\mathrm{p}<0.01, * * \mathrm{p}<0.05, * \mathrm{p}<0.1$

Table 5: Regression results for male first year students 


\begin{tabular}{|c|c|c|c|}
\hline \multicolumn{4}{|c|}{ Female first year students } \\
\hline MODEL & (1) & (2) & (3) \\
\hline fee & $\begin{array}{c}-223.4 * * * \\
(42.45)\end{array}$ & $\begin{array}{c}-262.2 * * * \\
(49.40)\end{array}$ & $\begin{array}{c}-156.4 * * * \\
(31.63)\end{array}$ \\
\hline distance $e^{4}$ & & $\begin{array}{c}6.06 \mathrm{e}-08 * * * \\
(1.79 \mathrm{e}-08)\end{array}$ & $\begin{array}{c}3.23 \mathrm{e}-08 * * * \\
\quad(7.88 \mathrm{e}-09)\end{array}$ \\
\hline ingfocus & $\begin{array}{l}-419.2 \\
(246.0)\end{array}$ & $\begin{array}{l}-418.1 \\
(247.8)\end{array}$ & \\
\hline elite & $\begin{array}{c}727.1 * * * \\
(181.7)\end{array}$ & $\begin{array}{c}638.0 * * * \\
(114.6)\end{array}$ & $\begin{array}{l}18.37 \\
(50.25)\end{array}$ \\
\hline graduates & $\begin{array}{l}0.153 \\
(0.186)\end{array}$ & $\begin{array}{l}0.142 \\
(0.181)\end{array}$ & $\begin{array}{l}0.184 * \\
(0.0905)\end{array}$ \\
\hline graduates $^{2}$ & $\begin{array}{l}4.53 \mathrm{e}-06 \\
(1.84 \mathrm{e}-05)\end{array}$ & $\begin{array}{l}5.38 \mathrm{e}-06 \\
(1.80 \mathrm{e}-05)\end{array}$ & $\begin{array}{c}-8.88 \mathrm{e}-06 \\
(7.83 \mathrm{e}-06)\end{array}$ \\
\hline unemployment & $\begin{array}{l}-4.307 \\
(25.31)\end{array}$ & $\begin{array}{l}5.700 \\
(22.15)\end{array}$ & $\begin{array}{l}27.38 \\
(19.97)\end{array}$ \\
\hline wagegap & $\begin{array}{l}514.5 \\
(673.7)\end{array}$ & $\begin{array}{l}592.6 \\
(649.9)\end{array}$ & $\begin{array}{l}380.4 \\
(490.4)\end{array}$ \\
\hline medianwage & $\begin{array}{l}867.4 \\
(1,625)\end{array}$ & $\begin{array}{l}634.2 \\
(1,549)\end{array}$ & $\begin{array}{l}27.22 \\
(1,178)\end{array}$ \\
\hline yeardummies & yes & yes & yes \\
\hline statedummies & yes & yes & \\
\hline Constant & $\begin{array}{l}-3,143 \\
(4,289)\end{array}$ & $\begin{array}{l}-2,833 \\
(3,940)\end{array}$ & $\begin{array}{l}309.3 \\
(3,061)\end{array}$ \\
\hline $\begin{array}{l}\text { Observations } \\
R^{2} \\
\text { Panel data }\end{array}$ & $\begin{array}{c}520 \\
0.393\end{array}$ & $\begin{array}{c}520 \\
0.396\end{array}$ & $\begin{array}{c}520 \\
0.358 \\
\text { FE }\end{array}$ \\
\hline $\begin{array}{l}\text { Clustered standarc } \\
* * * \mathrm{p}<0.01, * * \mathrm{p}\end{array}$ & $\begin{array}{l}\text { rrors in parent } \\
.05, * \mathrm{p}<0.1\end{array}$ & eses & \\
\hline
\end{tabular}


account. Furthermore, we find significant differences between males and females. It seems that male high school graduates react more sensitively to changes in economic variables such as the unemployment rate and the wage gap than their female counterparts.

\section{Fee and distance effects}

The coefficients of the dummy variable fee are negative and significant in all employed specifications and for both sexes. The effect on universities which charge fees is around -310 enrollees on average when looking at all first year students in the panel data model. ${ }^{12}$

As predicted, the variable distance ${ }^{4}$ positively affects the number of first year students. Thus, the larger the distance between a fee university and the nearest fee-free university, the smaller is the negative effect of tuition fees on enrollment rates. The distance variable is significant in the fixed effects model for all students and for males and females separately. The effect is particularly strong for females. Only in the OLS model it is insignificant for males but not for females and for all students.

Table 7 presents combined effect of both the fee variable and the distance variable on the number of first year students at fee universities. The figures are based on the fixed effects model (Model 3) and assess the combined effect for distance quartiles. The second column shows the average distance in each quartile, and the third, forth and fifth columns show the average effect on enrollment for all students, as well as for males and females, respectively, for each quartile.

\footnotetext{
${ }^{12}$ Note, however, that these results do not necessarily imply a negative effect of tuition fees on the transition of high school graduates to university, i.e., on the aggregate enrollment rate. Here, we measure the effect of tuitions fees on the number of enrollees at the individual university level. Bruckmeier and Wigger (2013) provide evidence that the aggregate enrollment rate is not affected by tuition fees. This result is consistent with the result that the number of enrollees decreases at feecharging universities, if one takes into account that students may avoid fees by studying at a fee-free university rather than a fee-charging one.
} 


\begin{tabular}{|c|c|lll|}
\hline Quartiles & Mean distance & \multicolumn{3}{|c|}{ Effect in percent } \\
& & All & Males & Females \\
1st & $58.5 \mathrm{~km}$ & -9.8 & -10.2 & -9.5 \\
2nd & $102.0 \mathrm{~km}$ & -11.0 & -12.9 & -10.0 \\
3rd & $129.9 \mathrm{~km}$ & -7.6 & -7.6 & -7.4 \\
4th & $210.3 \mathrm{~km}$ & -4.6 & -5.7 & -3.7 \\
\hline All & $124.7 \mathrm{~km}$ & -8.0 & -8.7 & -7.4 \\
\hline
\end{tabular}

Table 7: Combined effect of tuition fees and distance on the number of enrollees for distance quartiles

As one can see, the negative effect of tuition fees declines distinctly with distance. While the number of enrollees of universities in the 1st quartile declines by almost ten percent, the decline at universities in the 4th quartile amounts to less than five percent.

\section{Differences between males and females}

When analyzing men and women separately, the effect of the fee variable is of the same size in the panel data models (see Tables 5 and 6). Hence, there is no difference between the reaction of males and females regarding tuition fees in general. However, when it comes to the distance effect, males and females differ. The distance effect is significant in all but one mode $^{13}$, but the effect on women seems to be larger and with higher significance (Table 5 and 6). Concerning the total effect

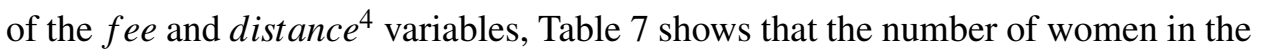
4th quartile is less affected by tuition fees $(-3.7 \%)$ than the number of men $(-5.8 \%)$. It seems that women are less fee-avoiding. A reason for this phenomenon could be that females, although they are more mobile in general, react, at the margin, less to economic incentives to commute or to migrate than their male counterparts.

\footnotetext{
${ }^{13}$ In Model 2 for male first year students the coefficient of the variable distance $e^{4}$ is not significantly different from zero but an F-test strongly rejects the hypothesis that the coefficients of both variables, fee and distance ${ }^{4}$, are jointly zero $(F=7,99, p=0,0043)$.
} 


\section{Adjusted control group}

The difference-in-differences approach we employ may overstate the negative effect of tuition fees on enrollment. This is because the introduction of tuition fees does not only affect the treatment group but also the control group. To the extent that students decide to choose a fee-free university instead of a fee-charging university that would have been their first choice in the absence of tuition fees, enrollment not only declines at fee-charging universities but also increases at fee-free universities. Thus, the negative effect of tuition fees at fee-charging universities also reflects the increase in enrollment at fee-free universities, when measured as differences in the development of enrollment at fee and fee-free universities. In order to correct for this effect, we considered an alternative scenario with an adjusted control group. In contrast to the control group in the base scenario, the adjusted control group only consists of those fee-free universities that are more than $200 \mathrm{~km}$ away from all fee universities in the winter term $2008 / 09^{14}$.

The underlying idea is that when a high school graduate decides to commute or to migrate to a fee-free university to avoid the fee at the university in the region where he or she lives, the high school graduate is more likely to choose a closer rather than a less close fee-free university. As a consequence, fee-avoiding commuting or migrating students should affect enrollment numbers of universities that are further away to a lesser extent than enrollment numbers of fee-free universities that are nearer by.

Table 8 presents the effect of the tuition and the distance variables on enrollment numbers at fee universities when the adjusted control group is considered. Compared to the results provided in Table 7 one can see that the distance effect on enrollment becomes stronger so that combined effect of tuition fees and distance on enrollment numbers becomes smaller.

\footnotetext{
${ }^{14}$ Consequently, all universities in the state of Hesse are excluded from this analysis.
} 


\begin{tabular}{|c|c|ccc|}
\hline Quartiles & Mean distance & \multicolumn{3}{|c|}{ Effect in percent } \\
& & All & Males & Females \\
1st & $60.8 \mathrm{~km}$ & -7.2 & -7.4 & -7.1 \\
2nd & $103.9 \mathrm{~km}$ & -7.6 & -8.6 & -6.9 \\
3rd & $130.7 \mathrm{~km}$ & -5.1 & -5.1 & -5.2 \\
4th & $211.8 \mathrm{~km}$ & -1.7 & -2.7 & -1.0 \\
\hline All & $126.4 \mathrm{~km}$ & -5.2 & -5.7 & -4.9 \\
\hline
\end{tabular}

Table 8: Combined effect of tuition fees and distance on the number of enrollees for distance quartiles; adjusted control group

\section{Robustness Checks}

We test the robustness of our results and apply the model specified in equation (2) to several alternative scenarios and adjusted datasets.

First we consider a modification of the distance measure. We repeat the fixed effects estimation with a polynomial distance term including distance, distance ${ }^{2}$, distance $^{3}$ and distance ${ }^{4}$. Table A2 shows the results for males and females. An Ftest strongly rejects the hypothesis that the coefficients of all fee related variables are jointly zero (total: $\mathrm{F}=23.55, \mathrm{p}=0.000$; males: $\mathrm{F}=39.19$, $\mathrm{p}=0.0000$; females: $\mathrm{F}=30.96, \mathrm{p}=0.0000$ ). Table 9 presents results on the combined effect of the fee and the distance variables on enrollment numbers at fee universities. The effects are close to the results of our base specification, with an overall negative effect of -8.7 percent compared to -8.0 percent (Table 7). Table 9 further shows that - except for the second quartile - the number of enrollees at fee universities that are further away from fee-free universities are less affected by the introduction of tuition fees. Again, this relationship seems to be stronger for female students than for male students.

In addition, we consider a semi-parametric fixed effects model based on Baltagi and $\mathrm{Li}$ (2002). The distance variable enters the model in a non-parametric form. ${ }^{15}$

\footnotetext{
${ }^{15}$ For the semi-parametric estimation we use the Stata command $x t$ semipar written by Libois and Verardi (2012).
} 


\begin{tabular}{|c|c|lll|}
\hline \multirow{2}{*}{ Quartiles } & Mean distance & \multicolumn{3}{|c|}{ Effect in percent } \\
& & All & Males & Females \\
1st & $58.5 \mathrm{~km}$ & -8.0 & -8.5 & -7.4 \\
2nd & $102.0 \mathrm{~km}$ & -10.5 & -11.5 & -9.9 \\
3rd & $129.9 \mathrm{~km}$ & -9.8 & -9.6 & -9.7 \\
4th & $210.3 \mathrm{~km}$ & -6.7 & -7.7 & -5.9 \\
\hline All & $124.7 \mathrm{~km}$ & -8.7 & -9.4 & -7.9 \\
\hline
\end{tabular}

Table 9: Combined effect of tuition fees and distance in the polynomial distance model

The resulting distance effect on enrollment numbers is shown in Figure 2. As one can see, the relationship between the distance of a fee university to the next feefree university and enrollment in the semi-parametric model is consistent with the results of our base specification. For fee universities that are further away from fee-free universities, the distance effect becomes stronger and, thus, dampens the negative effect of tuition fees on enrollment in a more pronounced way. For the maximum distance of 286 kilometers the distance effect on enrollment amounts to almost 300 students.

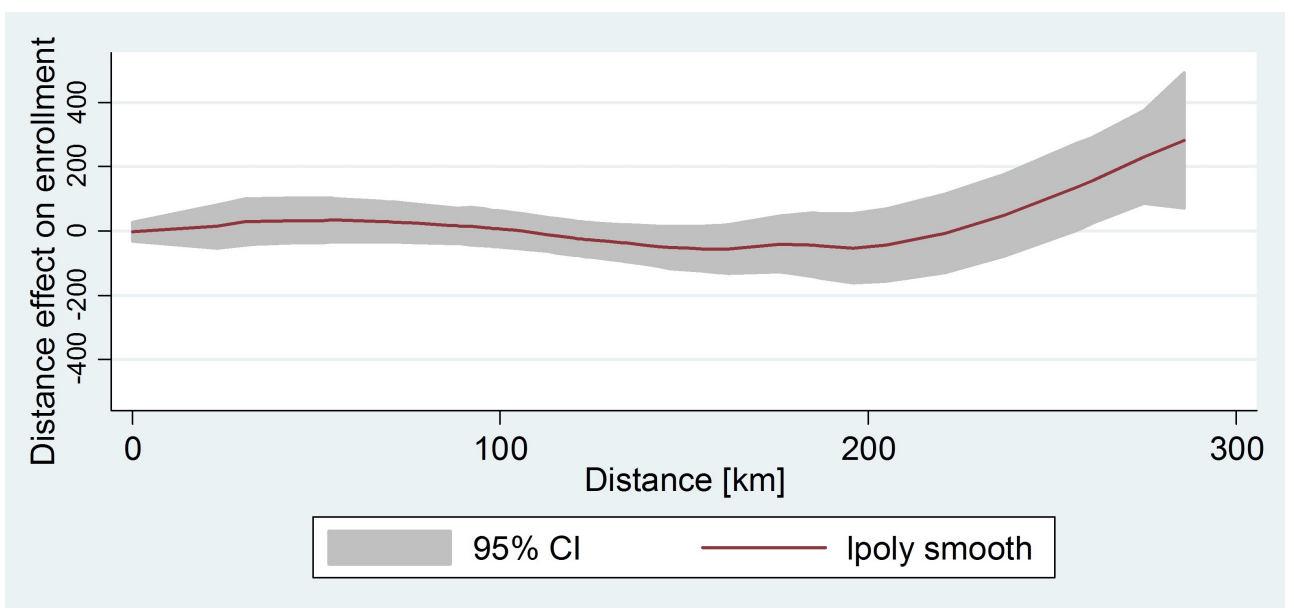

Figure 2: Distance effect in the semi-parametric model

Notes: University enrollment as a function of the distance to the next fee-free university. Estimated smooth based on local polynomial smoothing (mean) and 95 confidence intervals. 
Table 10 presents the combined effect of the fee and the distance variables on enrollment numbers at fee universities in the semi-parametric model. Again, the total effect on all first year students is close to the results obtained in our base model as shown in Table 7.

\begin{tabular}{|c|c|ccc|}
\hline \multirow{2}{*}{ Quartiles } & Mean distance & \multicolumn{3}{|c|}{ Effect in percent } \\
& & All & Males & Females \\
1st & $58.5 \mathrm{~km}$ & -7.8 & -5.8 & -9.5 \\
2nd & $102.0 \mathrm{~km}$ & -9.7 & -8.4 & -10.9 \\
3rd & $129.9 \mathrm{~km}$ & -7.7 & -6.3 & -8.9 \\
4th & $210.3 \mathrm{~km}$ & -6.3 & -5.9 & -6.6 \\
\hline All & $124.7 \mathrm{~km}$ & -7.8 & -6.5 & -8.8 \\
\hline
\end{tabular}

Table 10: Combined effect of tuition fees and distance in semi-parametric distance model

Next we consider an alternative treatment period in which treatment starts with the announcement of tuition fees rather than the implementation. In doing so, we use the first winter term after the decision of the respective state government to introduce tuition fees was announced (see Table 1 of Section 2). The respective results of Models 2 and 3, each for males and females, are shown in Table A3. As one can see, the effects are almost of the same size as in our base specification. Thus, considering announcement rather than implementation as the start of the treatment period does not alter our results.

To ensure that the effects we measure are associated with the introduction of tuition fees, we also consider a placebo treatment as of the winter term 2004/2005, where the treatment group consists of all federal states that introduced tuition fees later except the state of Hesse as this state only charged fees for one year and, therefore, is not comparable to the other federal states. The results shown in Table A4 reveal that the size of the fee effect decreases dramatically and is not significant anymore. This strongly supports our view that the fee and distance effects we 
measure in our base specification are associated with the introduction of tuition fees.

In order to address the potential problem of serial correlation within our dataset and the resulting downward biased standard errors, we consider, as an alternative, a pooled data set as recommended by Bertrand, Duflo and Mullainathan (2004). We define the before-treatment period by the years 2003-2006 and the treatment period by the years 2007-2010. We use averages of the control variables elite, graduates, graduates ${ }^{2}$, unemployment, wagegap, medianwage and the dependent variable $y$ in the two periods ( $t=$ before, after). As an alternative for timedummies we use the dummy variable after to indicate the treatment period as shown in the following equation,

$$
\bar{y}_{i s t}=\beta_{0}+\beta_{1} \text { fee }_{s}+\beta_{2}{\overline{\text { distance }^{4}}}_{i t}+\gamma \bar{X}_{i s t}^{\prime}+\text { after }+\rho_{s}+\varepsilon_{i s t} .
$$

The results are shown in Table A5. The variable fee takes on the value 1 in the treatment period for all federal states that introduced tuition fees. ${ }^{16}$ In order to calculate the distance variable we consider the time period after Hesse abolished fees and before Saarland abolished fees. This represents the longest period during which fees were in effect in the most states. The negative effect of tuition fees is still significant in all but one model. The distance effect is not significant for males. For women, in contrast, it is strongly significant and of about the same size as in our base specification. Thus, differences in the effect of tuition fees on male and female enrollment numbers appear to be very robust.

\footnotetext{
${ }^{16}$ The state of Hesse again has been excluded
} 


\section{Conclusion}

The introduction of tuition fees at public universities in seven out of the sixteen federal states in Germany can be seen as a 'natural experiment'. We use this experiment to identify the effects of tuition fees on enrollment at public universities in Germany. In contrast to former studies we do not only consider the decision of whether or not to study but also of where to study. In the German case this is of particular interest as students can more or less easily avoid tuition fees by enrolling at a university in a fee-free state. In order to model the decision of where to study, we take into account the location of universities by including a spatial variable. This variable measures the distance from each fee-charging university to the nearest fee-free university.

Based on administrative data of all major universities in Germany, we find a negative effect of tuition fees on average enrollment of first year students at fee-charging universities of between 7 and 8 percent, depending on the specific scenario. However, the negative effect of tuition fees on enrollment numbers distinctly declines with the fee-charging university's distance to the nearest fee-free university. For those fee-charging universities that are furthest away from fee-free universities, the negative effect of tuition fees on enrollment numbers declines to between 2 and 4 percent. Students living close to fee-free universities can easily avoid tuition fees, whereas students living further away face higher mobility costs. As a consequence, fee-charging universities that are closer to fee-free universities experience a greater decline in enrollment numbers after the introduction of tuition fees. The negative effect of tuition fees on enrollment numbers of fee-charging universities should not be confused, however, with a negative effect of tuition fees on aggregate enrollment rates, i.e., the rate of transition from high school to university. As Bruckmeier and Wigger (2013) have shown, there is no evidence that the introduction of tuition fees at public universities in some German states has led 
to a decrease in aggregate enrollment rates. Taken together with the results of the present paper, this implies that potential students avoid tuition fees by moving to a fee-free university rather than by deciding not to study.

Our results also reveal gender differences in enrollment behavior. Enrollment numbers of female students at universities that are further away from any fee-free alternative are significantly less affected by the introduction of tuition fees than enrollment numbers of male students. Since females' enrollment behavior is also less affected by other economic variables such as the regional employment rate and the gap between the wages of university graduates and other workers, it seems that the migration decision of females is less driven by concerns about the costs and returns of higher education than the respective decision of males.

Being confronted with either paying tuition fees or incurring mobility costs, students will, ceteris paribus, opt for the less costly alternative. From a welfare point of view, however, these two types of costs differ substantially. Costs in the form of tuition fees imply revenue on the side of the fee-charging university, which can be used to improve higher education quality or to save public funds. Mobility costs, in contrast, are a pure dead weight loss and, thus, constitute a strict welfare loss. This should be taken into account when implementing tuition fees at public universities. One possibility to diminish the welfare loss is to charge lower fees at those universities in fee-charging states that are close to fee-free universities. This is the tuition fee analog to the lesson from optimal taxation that elastic tax bases should be taxed less than inelastic ones. A second, more effective possibility would be to coordinate higher education financing between the German states and to charge tuition fees at all public universities in Germany. This, in turn, is the tuition fee analog to the optimal taxation lesson that tax bases should be defined as broadly as possible. 


\section{References}

Alecke, B./Mitze, T. (2012): Studiengebühren und das Wanderungsverhalten von Studienanfängern: eine panel-ökonometrische Wirkungsanalyse. Perspektiven der Wirtschaftspolitik, 13 No. 4, 357-386

Angrist, J. D./Pischke, J. S. (2009): Mostly harmless econometrics: An empiricist's companion. Princeton: Princeton University Press

Baltagi, B. H./Li, D. (2002): Series estimation of partially linear panel data models with fixed effects. Annals of Economic and Finance, 3, 103

Bertrand, M./Duflo, E./Mullainathan, S. (2004): How Much Should We Trust Differences-In-Differences Estimates? The Quarterly Journal of Economics, 119 No. 1, 249-275

Bruckmeier, K./Wigger, B.U. (2013): The effects of tuition fees on transition from high school to university in Germany. CESifo - Discussion Paper

Büttner, T./Kraus, M./Rincke, J. (2003): Hochschulranglisten als Qualitätsindikatoren im Wettbewerb der Hochschulen. Vierteljahrshefte zur Wirtschaftsforschung, 72 No. 2, 252-270

CESifo (2011): Tuition Fees in Europe 2010/2011. CESifo - DICE Report 9 (1), pages 53-55

Dearden, L./Fitzsimons, E./Wyness, G. (2011): The Impact of Tuition Fees and Support on University Participation in the UK. Institute for Fiscal Studies IFS Working Paper W11/17

Denzler, S./Wolter, S.C. (2010): Der Einfluss des lokalen Hochschulangebots auf die Studienwahl. Zeitschrift für Erziehungswissenschaft, 13 No. 4, 683-706

Donald, S.G./Lang, K. (2007): Inference with difference-in-differences and other panel data. The Review of Economics and Statistics, 89 No. 2, 221-233

Dwenger, N./Storck, J./Wrohlich, K. (2012): Do tuition fees affect the mobility of university applicants? Evidence from a natural experiment. Economics of Education Review, 31 No. 1, 155-167 
Helbig, M./Baier, T./Kroth, A. (2012): Die Auswirkung von Studiengebühren auf die Studierneigung in Deutschland. Evidenz aus einem natürlichen Experiment auf Basis der HIS-Studienberechtigtenbefragung. Zeitschrift für Soziologie, 41 No. 3, 227-246

Heller, D.E. (1997): Student Price Response in Higher Education: An Update to Leslie and Brinkman. Journal of Higher Education, 68 No. 6, 624-59

Hemelt, S./Marcotte, D. (2008): Rising tuition and enrollment in public higher education. IZA - Discussion Paper No. 3827

Hübner, M. (2012): Do tuition fees affect enrollment behavior? Evidence from a "natural experiment" in Germany. Economics of Education Review, 31 No. 6, 949-960

Kane, T. J. (1994): College Entry by Blacks since 1970: The Role of College Costs, Family Background, and the Returns to Education. The Journal of Political Economy, 102 No. 5, 878-911

Leslie, L.L./Brinkman, P.T. (1987): Student Price Response in Higher Education: The Student Demand Studies. Journal of Higher Education, 58 No. 2, 181204

Liang, K.Y./Zeger, S.L. (1986): Longitudinal data analysis using generalized linear models. Biometrika, 73 No. 1, 13-22

Libois, F./Verardi, V. (2012): Semiparametric Fixed-Effects Estimator. Center for Research in the Economics of Development - Department of Economics Working Paper WP 1201

Moulton, B.R. (1986): Random group effects and the precision of regression estimates. Journal of Econometrics, 32 No. 3, 385-397

Moulton, B.R. (1990): An Illustration of a Pitfall in Estimating the Effects of Aggregate Variables on Micro Unit. The Review of Economics and Statistics, 72 No. 2, 334-38

OECD (2011): Education at a Glance 2011 - OECD Indicators. Paris

Spiess, C.K./Wrohlich, K. (2010): Does distance determine who attends a university in Germany? Economics of Education Review, 29 No. 3, 470-479 
Statistisches Bundesamt (2004): Studierende an Hochschulen. Wiesbaden

Statistisches Bundesamt (2011): Studierende an Hochschulen. Wiesbaden

Wilkins, S./Shams, F./Huisman, J. (2012): The decision-making and changing behavioural dynamics of potential higher education students: the impacts of increasing tuition fees in England. Educational Studies, 0 No. 0, 1-17 〈URL: http://www.tandfonline.com/doi/abs/10.1080/03055698. $2012.681360\rangle$

Winter-Ebmer, R./Wirz, A. (2002): Public funding and enrolment into higher education in Europe. IZA - Discussion paper series, No. 503 


\section{A Appendix}

Table A1: First year students by field of study

\begin{tabular}{lcccc}
\hline Year & \multicolumn{2}{c}{2000} & \multicolumn{2}{c}{2010} \\
\hline & Count & Share & Count & Share \\
\hline Languages and arts & 62,521 & $19.9 \%$ & 77,051 & $17.3 \%$ \\
Legal, economic and social sciences & 106.980 & $34.0 \%$ & 148,368 & $33.4 \%$ \\
Mathematics, natural sciences & 58,809 & $18.7 \%$ & 74,878 & $16.8 \%$ \\
Human medicine & 11,565 & $3.7 \%$ & 19,682 & $4.4 \%$ \\
Engineering & 52,797 & $16.8 \%$ & 93,417 & $21.0 \%$ \\
Other & 21,867 & $7.0 \%$ & 31,212 & $7.0 \%$ \\
\hline Total & $\mathbf{3 1 4 , 5 3 9}$ & $\mathbf{1 0 0 . 0 \%}$ & $\mathbf{4 4 4 , 6 0 8}$ & $\mathbf{1 0 0 . 0 \%}$
\end{tabular}

Source: Statistisches Bundesamt (2004), Statistisches Bundesamt (2011) and own calculations. 
Table A2: Analysis with polynomial distance term

\begin{tabular}{|c|c|c|c|}
\hline GENDER & Total & $\mathrm{M}$ & $\mathrm{F}$ \\
\hline fee & $\begin{array}{l}-988.6^{*} \\
(494.0)\end{array}$ & $\begin{array}{c}-565.5^{* *} \\
(251.9)\end{array}$ & $\begin{array}{l}-421.7 \\
(271.7)\end{array}$ \\
\hline distance & $\begin{array}{c}30.37 \\
(21.03)\end{array}$ & $\begin{array}{c}17.10 \\
(10.35)\end{array}$ & $\begin{array}{c}13.17 \\
(11.53)\end{array}$ \\
\hline distance $^{2}$ & $\begin{array}{l}-0.380 \\
(0.275)\end{array}$ & $\begin{array}{l}-0.203 \\
(0.136)\end{array}$ & $\begin{array}{l}-0.175 \\
(0.147)\end{array}$ \\
\hline distance $^{3}$ & $\begin{array}{c}0.00173 \\
(0.00135)\end{array}$ & $\begin{array}{c}0.000883 \\
(0.000684)\end{array}$ & $\begin{array}{c}0.000832 \\
(0.000709)\end{array}$ \\
\hline distance $^{4}$ & $\begin{array}{l}-2.54 \mathrm{e}-06 \\
(2.24 \mathrm{e}-06)\end{array}$ & $\begin{array}{c}-1.25 \mathrm{e}-06 \\
(1.15 \mathrm{e}-06)\end{array}$ & $\begin{array}{c}-1.26 \mathrm{e}-06 \\
(1.15 \mathrm{e}-06)\end{array}$ \\
\hline elite & $\begin{array}{c}168.9 \\
(185.9)\end{array}$ & $\begin{array}{c}151.7 \\
(128.8)\end{array}$ & $\begin{array}{c}15.14 \\
(71.83)\end{array}$ \\
\hline graduates & $\begin{array}{c}0.167^{*} \\
(0.0924)\end{array}$ & $\begin{array}{c}0.155^{*} \\
(0.0852)\end{array}$ & $\begin{array}{c}0.171^{*} \\
(0.0908)\end{array}$ \\
\hline graduates $^{2}$ & $\begin{array}{l}-3.72 \mathrm{e}-06 \\
(4.36 \mathrm{e}-06)\end{array}$ & $\begin{array}{l}-7.17 e-06 \\
(9.33 e-06)\end{array}$ & $\begin{array}{c}-7.56 \mathrm{e}-06 \\
(7.80 \mathrm{e}-06)\end{array}$ \\
\hline unemployment & $\begin{array}{c}51.55 \\
(32.30)\end{array}$ & $\begin{array}{l}27.44 * \\
(14.46)\end{array}$ & $\begin{array}{c}24.81 \\
(20.44)\end{array}$ \\
\hline wagegap & $\begin{array}{c}836.5 \\
(620.5)\end{array}$ & $\begin{array}{c}477.8 \\
(282.2)\end{array}$ & $\begin{array}{c}314.2 \\
(476.0)\end{array}$ \\
\hline medianwage & $\begin{array}{c}191.0 \\
(2,410)\end{array}$ & $\begin{array}{l}-162.6 \\
(1,203)\end{array}$ & $\begin{array}{c}360.2 \\
(1,264)\end{array}$ \\
\hline $\begin{array}{l}\text { yeardummies } \\
\text { statedummies }\end{array}$ & yes & yes & yes \\
\hline Constant & $\begin{array}{c}689.0 \\
(3,391)\end{array}$ & $\begin{array}{l}-413.0 \\
(3,295)\end{array}$ & \\
\hline Observations & 520 & 520 & 520 \\
\hline $\begin{array}{l}R^{2} \\
\text { Panel data }\end{array}$ & $\begin{array}{c}0.409 \\
\mathrm{FE}\end{array}$ & $\begin{array}{c}0.378 \\
\mathrm{FE}\end{array}$ & 0.366 \\
\hline
\end{tabular}

Clustered standard errors in parentheses $* * * \mathrm{p}<0.01, * * \mathrm{p}<0.05, * \mathrm{p}<0.1$ 
Table A3: Treatment period starting with the announcement of introduction

\begin{tabular}{|c|c|c|c|c|}
\hline MODEL & \multicolumn{2}{|c|}{ (2) } & \multicolumn{2}{|c|}{ (3) } \\
\hline GENDER & $\mathrm{M}$ & $\mathrm{F}$ & $\mathrm{M}$ & $\mathrm{F}$ \\
\hline fee & $\begin{array}{c}-210.9 * * * \\
(70.68)\end{array}$ & $\begin{array}{c}-235.1 * * * \\
(47.63)\end{array}$ & $\begin{array}{c}-171.6 * * * \\
(41.05)\end{array}$ & $\begin{array}{c}-143.7 * * * \\
(38.35)\end{array}$ \\
\hline distance $^{4}$ & $\begin{array}{c}2.76 \mathrm{e}-08^{* * *} \\
(6.12 \mathrm{e}-09)\end{array}$ & $\begin{array}{c}7.54 \mathrm{e}-08^{* * *} \\
(2.06 \mathrm{e}-08)\end{array}$ & $\begin{array}{c}4.32 \mathrm{e}-08^{* * *} \\
(1.04 \mathrm{e}-08)\end{array}$ & $\begin{array}{c}3.96 \mathrm{e}-08^{* * * *} \\
(7.13 \mathrm{e}-09)\end{array}$ \\
\hline ingfocus & $\begin{array}{c}1,254 * * * \\
(145.3)\end{array}$ & $\begin{array}{l}-418.8 \\
(250.4)\end{array}$ & & \\
\hline elite & $\begin{array}{c}685.6 * * * \\
(164.7)\end{array}$ & $\begin{array}{c}607.4 * * * \\
(90.68)\end{array}$ & $\begin{array}{c}130.1 \\
(100.5)\end{array}$ & $\begin{array}{c}9.647 \\
(50.45)\end{array}$ \\
\hline graduates & $\begin{array}{l}0.0496 \\
(0.130)\end{array}$ & $\begin{array}{c}0.137 \\
(0.175)\end{array}$ & $\begin{array}{c}0.190^{*} \\
(0.0936)\end{array}$ & $\begin{array}{c}0.187^{*} \\
(0.0892)\end{array}$ \\
\hline graduates $^{2}$ & $\begin{array}{c}1.38 \mathrm{e}-05 \\
(1.59 \mathrm{e}-05)\end{array}$ & $\begin{array}{c}5.66 \mathrm{e}-06 \\
(1.77 \mathrm{e}-05)\end{array}$ & $\begin{array}{l}-9.93 e-06 \\
(9.59 e-06)\end{array}$ & $\begin{array}{l}-9.16 \mathrm{e}-06 \\
(7.68 \mathrm{e}-06)\end{array}$ \\
\hline unemployment & $\begin{array}{l}-3.483 \\
(25.20)\end{array}$ & $\begin{array}{c}0.812 \\
(22.48)\end{array}$ & $\begin{array}{l}29.29^{*} \\
(13.84)\end{array}$ & $\begin{array}{c}23.98 \\
(18.52)\end{array}$ \\
\hline wagegap & $\begin{array}{l}-66.84 \\
(755.4)\end{array}$ & $\begin{array}{c}638.4 \\
(670.9)\end{array}$ & $\begin{array}{l}708.1 * * \\
(304.4)\end{array}$ & $\begin{array}{c}441.2 \\
(504.7)\end{array}$ \\
\hline medianwage & $\begin{array}{c}509.4 \\
(1,652)\end{array}$ & $\begin{array}{c}510.0 \\
(1,422)\end{array}$ & $\begin{array}{l}-466.1 \\
(969.9)\end{array}$ & $\begin{array}{l}-26.90 \\
(1,013)\end{array}$ \\
\hline yeardummies & yes & yes & yes & yes \\
\hline statedummies & yes & yes & & \\
\hline Constant & $\begin{array}{l}-1,190 \\
(4,557)\end{array}$ & $\begin{array}{l}-2,418 \\
(3,723)\end{array}$ & $\begin{array}{c}1,042 \\
(2,716)\end{array}$ & $\begin{array}{c}361.0 \\
(2,702)\end{array}$ \\
\hline Observations & 520 & 520 & 520 & 520 \\
\hline$R^{2}$ & 0.691 & 0.398 & 0.377 & 0.355 \\
\hline Panel data & & & FE & FE \\
\hline
\end{tabular}

Clustered standard errors in parentheses

$* * * \mathrm{p}<0.01, * * \mathrm{p}<0.05, * \mathrm{p}<0.1$ 
Table A4: Placebo-fee as of winter term 2004/2005

\begin{tabular}{|c|c|c|c|c|}
\hline \multirow{2}{*}{$\begin{array}{l}\text { MODEL } \\
\text { GENDER }\end{array}$} & \multicolumn{2}{|c|}{ (2) } & \multicolumn{2}{|c|}{ (4) } \\
\hline & $\mathrm{M}$ & $\mathrm{F}$ & $\mathrm{M}$ & $\mathrm{F}$ \\
\hline fee & $\begin{array}{l}-42.01 \\
(74.00)\end{array}$ & $\begin{array}{l}-66.16 \\
(105.9)\end{array}$ & $\begin{array}{l}-66.58 \\
(55.41)\end{array}$ & $\begin{array}{l}-33.50 \\
(77.30)\end{array}$ \\
\hline distance $^{4}$ & $\begin{array}{c}3.15 \mathrm{e}-08 * * * \\
(8.59 \mathrm{e}-09)\end{array}$ & $\begin{array}{c}9.19 \mathrm{e}-08 * * * \\
(2.65 \mathrm{e}-08)\end{array}$ & $\begin{array}{c}3.27 \mathrm{e}-08 * * \\
(1.14 \mathrm{e}-08)\end{array}$ & $\begin{array}{c}3.88 \mathrm{e}-08 * * * \\
(8.25 \mathrm{e}-09)\end{array}$ \\
\hline ingfocus & $\begin{array}{c}1,295 * * * \\
(161.9)\end{array}$ & $\begin{array}{l}-340.9 \\
(289.9)\end{array}$ & & \\
\hline elite & $\begin{array}{c}683.5 * * * \\
(157.6)\end{array}$ & $\begin{array}{c}580.1 * * * \\
(99.44)\end{array}$ & $\begin{array}{c}169.0 \\
(106.1)\end{array}$ & $\begin{array}{c}29.40 \\
(59.94)\end{array}$ \\
\hline graduates & $\begin{array}{l}0.0344 \\
(0.140)\end{array}$ & $\begin{array}{l}0.0784 \\
(0.187)\end{array}$ & $\begin{array}{l}0.212 * * \\
(0.0989)\end{array}$ & $\begin{array}{c}0.202 * \\
(0.0944)\end{array}$ \\
\hline graduates $^{2}$ & $\begin{array}{c}1.53 \mathrm{e}-05 \\
(1.74 \mathrm{e}-05)\end{array}$ & $\begin{array}{c}1.06 \mathrm{e}-05 \\
(1.91 \mathrm{e}-05)\end{array}$ & $\begin{array}{c}-1.12 \mathrm{e}-05 \\
(1.00 \mathrm{e}-05)\end{array}$ & $\begin{array}{l}-1.06 \mathrm{e}-05 \\
(8.12 \mathrm{e}-06)\end{array}$ \\
\hline unemployment & $\begin{array}{l}-27.39 \\
(25.75)\end{array}$ & $\begin{array}{l}-20.73 \\
(31.05)\end{array}$ & $\begin{array}{c}11.65 \\
(15.93)\end{array}$ & $\begin{array}{c}13.32 \\
(25.01)\end{array}$ \\
\hline wagegap & $\begin{array}{l}-572.9 \\
(600.9)\end{array}$ & $\begin{array}{l}-112.6 \\
(855.6)\end{array}$ & $\begin{array}{c}473.1 \\
(330.8)\end{array}$ & $\begin{array}{c}161.9 \\
(698.3)\end{array}$ \\
\hline medianwage & $\begin{array}{l}-529.0 \\
(1,501)\end{array}$ & $\begin{array}{l}-275.7 \\
(1,449)\end{array}$ & $\begin{array}{l}-1,208 \\
(1,039)\end{array}$ & $\begin{array}{c}-824.4 \\
(1,283)\end{array}$ \\
\hline yeardummies & yes & yes & yes & yes \\
\hline statedummies & yes & yes & & \\
\hline Constant & $\begin{array}{c}2,719 \\
(3,749)\end{array}$ & $\begin{array}{c}1,176 \\
(3,830)\end{array}$ & $\begin{array}{c}3,432 \\
(2,813)\end{array}$ & $\begin{array}{c}2,891 \\
(3,329)\end{array}$ \\
\hline $\begin{array}{l}\text { Observations } \\
R^{2} \\
\text { Panel data }\end{array}$ & $\begin{array}{c}480 \\
0.693\end{array}$ & $\begin{array}{c}480 \\
0.384\end{array}$ & $\begin{array}{c}480 \\
0.345 \\
\text { FE }\end{array}$ & $\begin{array}{c}480 \\
0.319 \\
\text { FE }\end{array}$ \\
\hline
\end{tabular}

Clustered standard errors in parentheses

$* * * \mathrm{p}<0.01, * * \mathrm{p}<0.05, * \mathrm{p}<0.1$ 
Table A5: Analysis with pooled dataset (before and after treatment)

\begin{tabular}{|c|c|c|c|c|}
\hline MODEL & \multicolumn{2}{|c|}{ (2) } & \multicolumn{2}{|c|}{ (3) } \\
\hline GENDER & M & $\mathrm{F}$ & M & $\mathrm{F}$ \\
\hline fee & $\begin{array}{l}-97.61 \\
(140.4)\end{array}$ & $\begin{array}{l}-216.1 * \\
(119.0)\end{array}$ & $\begin{array}{c}-103.0 * * \\
(36.23)\end{array}$ & $\begin{array}{l}-145.5^{*} \\
(77.37)\end{array}$ \\
\hline distance $^{4}$ & $\begin{array}{c}-1.87 \mathrm{e}-08 \\
(1.53 \mathrm{e}-08)\end{array}$ & $\begin{array}{c}4.98 \mathrm{e}-08 * * \\
(2.10 \mathrm{e}-08)\end{array}$ & $\begin{array}{c}1.83 \mathrm{e}-08 \\
(1.41 \mathrm{e}-08)\end{array}$ & $\begin{array}{c}3.29 \mathrm{e}-08 * * * \\
(9.14 \mathrm{e}-09)\end{array}$ \\
\hline after & $\begin{array}{l}-98.65 \\
(597.2)\end{array}$ & $\begin{array}{c}444.1 \\
(465.7)\end{array}$ & $\begin{array}{l}367.8^{*} \\
(172.2)\end{array}$ & $\begin{array}{c}578.6^{* *} \\
(242.4)\end{array}$ \\
\hline ingfocus & $\begin{array}{c}1,286 * * * \\
(165.6)\end{array}$ & $\begin{array}{l}-337.6 \\
(312.2)\end{array}$ & & \\
\hline elite & $\begin{array}{c}914.9 * * * \\
(248.7)\end{array}$ & $\begin{array}{c}794.7 * * * \\
(169.9)\end{array}$ & $\begin{array}{c}209.2 \\
(136.3)\end{array}$ & $\begin{array}{c}49.40 \\
(90.96)\end{array}$ \\
\hline graduates & $\begin{array}{l}0.0124 \\
(0.173)\end{array}$ & $\begin{array}{l}0.0376 \\
(0.253)\end{array}$ & $\begin{array}{c}0.507 * * \\
(0.210)\end{array}$ & $\begin{array}{c}0.345 \\
(0.294)\end{array}$ \\
\hline graduates $^{2}$ & $\begin{array}{c}2.16 \mathrm{e}-05 \\
(2.20 \mathrm{e}-05)\end{array}$ & $\begin{array}{c}1.92 \mathrm{e}-05 \\
(2.64 \mathrm{e}-05)\end{array}$ & $\begin{array}{l}-2.80 \mathrm{e}-05 \\
(1.69 \mathrm{e}-05)\end{array}$ & $\begin{array}{l}-7.75 e-06 \\
(2.42 e-05)\end{array}$ \\
\hline unemployment_rate & $\begin{array}{l}-37.90 \\
(72.22)\end{array}$ & $\begin{array}{c}41.19 \\
(59.16)\end{array}$ & $\begin{array}{c}30.30 \\
(24.07)\end{array}$ & $\begin{array}{c}53.47 \\
(40.75)\end{array}$ \\
\hline wage_gap & $\begin{array}{l}-1,479 \\
(1,795)\end{array}$ & $\begin{array}{c}680.3 \\
(1,208)\end{array}$ & $\begin{array}{c}1,365 * * \\
(615.6)\end{array}$ & $\begin{array}{c}1,640 \\
(1,209)\end{array}$ \\
\hline median_wage & $\begin{array}{l}-325.4 \\
(3,412)\end{array}$ & $\begin{array}{l}-1,977 \\
(2,693)\end{array}$ & $\begin{array}{l}-2,257^{*} \\
(1,200)\end{array}$ & $\begin{array}{l}-2,504 \\
(1,773)\end{array}$ \\
\hline yeardummies & & & & \\
\hline statedummies & yes & yes & & \\
\hline Constant & $\begin{array}{c}3,527 \\
(8,946)\end{array}$ & $\begin{array}{c}2,473 \\
(7,475)\end{array}$ & $\begin{array}{c}3,452 \\
(3,216)\end{array}$ & $\begin{array}{c}3,535 \\
(4,575)\end{array}$ \\
\hline Observations & 120 & 120 & 120 & 120 \\
\hline$R^{2}$ & 0.715 & 0.397 & 0.432 & 0.513 \\
\hline Panel data & & & FE & FE \\
\hline
\end{tabular}

